\title{
Treatment of a malignant peripheral nerve sheath tumor by intravenous administration of combretastatin A4-phosphate in a dog
}

\author{
Behandeling van een maligne perifere zenuwschedetumor door intraveneuze \\ toediening van combretastatine A4-fosfaat bij een hond
}

${ }^{1,2}$ S. De Vos, ${ }^{1}$ E. Abma, ${ }^{3}$ K. Vanderperren, ${ }^{4} \mathrm{~L}$. Van Brantegem, ${ }^{2} \mathrm{~W}$. De Spiegelaere, ${ }^{1} \mathrm{H}$. de Rooster

${ }^{1}$ Small Animal Department

${ }^{2}$ Department of Morphology

${ }^{3}$ Department of Medical imaging of Domestic Animals and Orthopedics of Small Animals

${ }^{4}$ Department of Pathology, Bacteriology and Poultry Diseases

Faculty of Veterinary Medicine, Ghent University, Salisburylaan 133, B-9820 Merelbeke, Belgium

\section{Shana.DeVos@UGent.be}

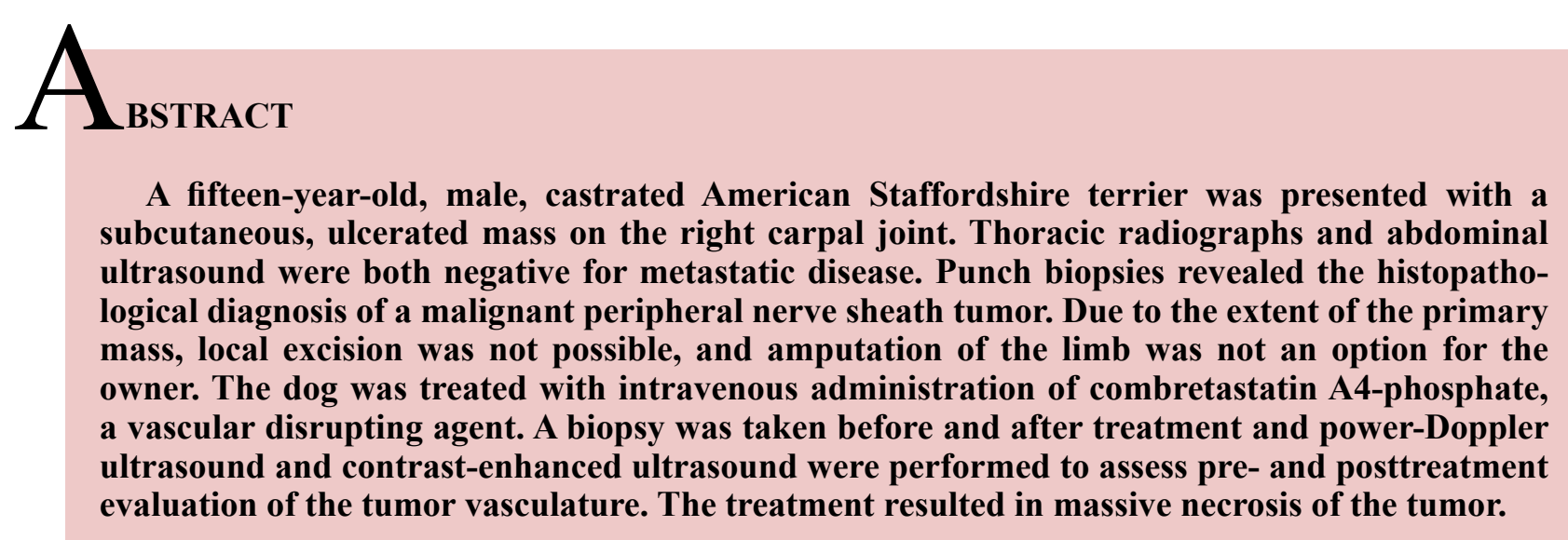

\section{SAMENVATTING}

Een vijftienjarige, mannelijke, gecastreerde Amerikaanse staffordshireterriër werd aangeboden met een subcutane, ulceratieve massa ter hoogte van het rechter carpaal gewricht. Thoraxradiografieën en een abdominale echografie waren beide negatief voor metastasen. Er werden punchbiopten genomen van de massa waaruit histopathologisch een maligne perifere zenuwschedetumor werd gediagnosticeerd. Doordat de primaire massa zo uitgebreid was, was chirurgische excisie onmogelijk en amputatie van de voorpoot was geen optie voor de eigenaar. De hond werd intraveneus behandeld met combretastatin A4-phosphate, een stof die het cytoskelet van immature bloedvaten verstoord. Voor en na de behandeling werd een biopt genomen en via "power-doppler ultrasound" en contrastechografie werd de doorbloeding van de tumor voor en na de therapie opgevolgd. De behandeling resulteerde in massale necrose van de tumor.

\section{INTRODUCTION}

Cancer is an important cause of death in companion animals (Farese et al., 2012). Pets with cancer often have very advanced (locally invasive and/or metastatic) disease when presented to a veterinarian (Farese et al., 2012).

Soft tissue sarcomas, such as peripheral nerve sheath tumors (PNST), are a heterogenous population of mesenchymal tumors that comprise around $15 \%$ and $7 \%$ of all skin and subcutaneous tumors in dogs and cats, respectively (Liptak and Forrest, 2013). Most dogs that are presented with a soft tissue sarcoma are between three and twelve years old (Targett et al., 1993). There is no specific breed or sex predilection for soft tissue sarcomas (Liptak and Forrest, 2013). PNSTs are most commonly located on the extremities (Brehm et al., 1995). In the early stage of the disease, 
clinical presentation of a PNST is indistinguishable from other causes of lameness (da Costa et al., 2008). Treatment consists of surgical excision, amputation of the affected limb, radiation or, sometimes, palliative administration of corticosteroids (Targett et al., 1993; Saunders et al., 1998).

Whenever surgery is not an option, other therapies might have potential. Apart from chemotherapy and radiation, the use of drugs such as vascular disruptive agents (VDA) might be explored. Treatment with a VDA is not yet approved by the US Food and Drug Administration (FDA) in companion animals, but recent (pre)clinical studies in dogs have demonstrated positive results (Abma et al., 2017; Abma et al., 2018).

Combretastatin A4-phosphate (CA4P) is a vascular disrupting agent that is originally derived from the tree called "Combretum caffrum", a South African willow. It is a tubulin-binding agent that destabilizes the microtubules and disrupts the endothelial cells of the immature tumoral vasculature (Young and Chaplin, 2004), leading to endothelial cell death and resulting in ischemia and necrosis of the tumor cells (Kanthou et al., 2004). CA4P is an effective antivascular agent that interferes with regrowth of blood vessels by activating cell death pathways (Kanthou et al., 2004). Vascular disrupting agents such as CA4P are very specific and also selective in their target for vascularization because they only focus on the immature vessels. Immature vasculature present in the central part of the tumor is sensitive, whereas vessels of the periphery and surrounding normal tissues are mature and therefore will not be destroyed (Siemann et al., 2005). Despite its selectivity, there is proof that CA4P

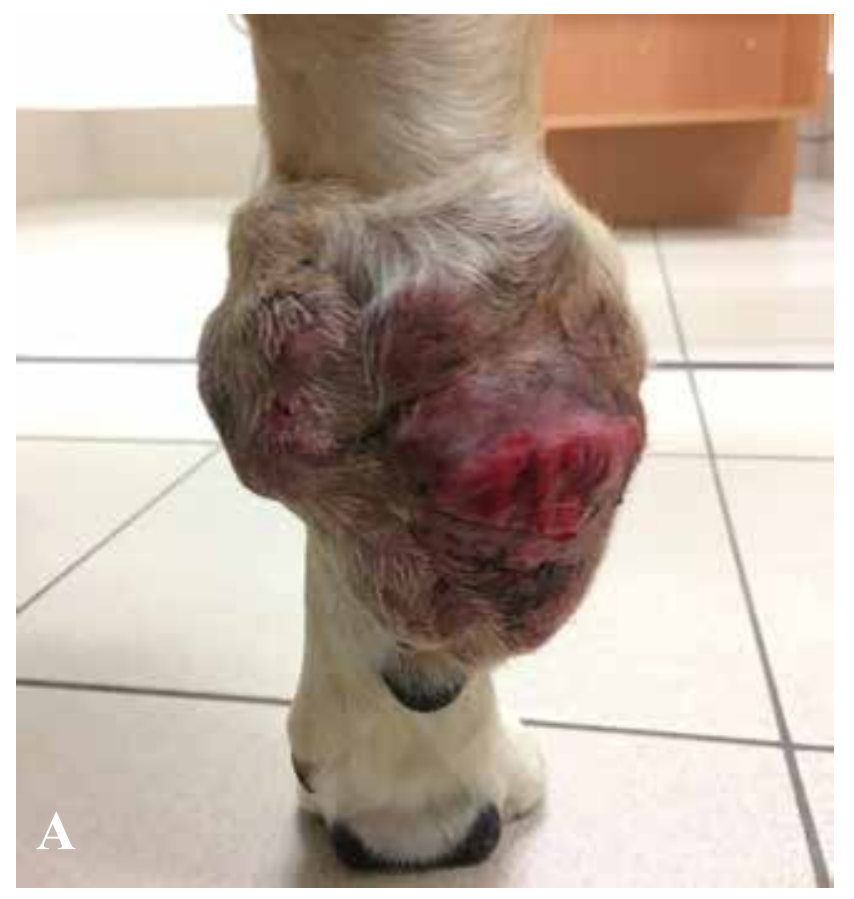

can be toxic for dividing endothelial cells after prolonged exposure (Galbraith et al., 2001). In animals, it has been confirmed that dividing cells that are present in the gastrointestinal tract and lymphoid tissues, are affected when CA4P is administered at or above the maximum tolerated dose (Zweifel and Rustin, 2010).

In this case report, a fifteen-year-old dog with an inoperable PNST on the carpus that received CA4P treatment, is described. Special attention is given to the different methods that can be used to assess the treatment effect of such vascular disruptive agent and the clinical results of treatment with CA4P.

\section{CASE REPORT}

A fifteen-year-old, male, castrated American Staffordshire terrier was presented with a large mass on the right carpal joint. In the past, a PNST had already been removed twice from the same location. On both occasions, it recurred after six months. The present mass had been growing slowly but consistently over the past year. Despite the extent of the tumor, the dog was not lame.

On physical examination, no abnormalities were found apart from the presence of the mass. The tumor itself was solid with an ulcerative and reddish aspect, and the surrounding tissue was swollen (Figure 1A). Blood analysis did not reveal any abnormalities. Metastasis was ruled out by thoracic radiographs and a complete ultrasound examination of the abdomen.

Local excision, even if marginally, was not an option due to the size of the mass. Therefore, limb ampu-

Figure 1 A. Caudal view of the ulcerative and solid tumoral mass at the level of the right carpal joint of a 15-year-old American Staffordshire terrier. B. Macroscopic view of the tumor three weeks after treatment. The mass decreased in size and the overlying skin had a less irritated and less ulcerative aspect. Regions where the biopsies were taken could be seen as small circular wounds (https://doi.org/10.1111/vco.12402). 

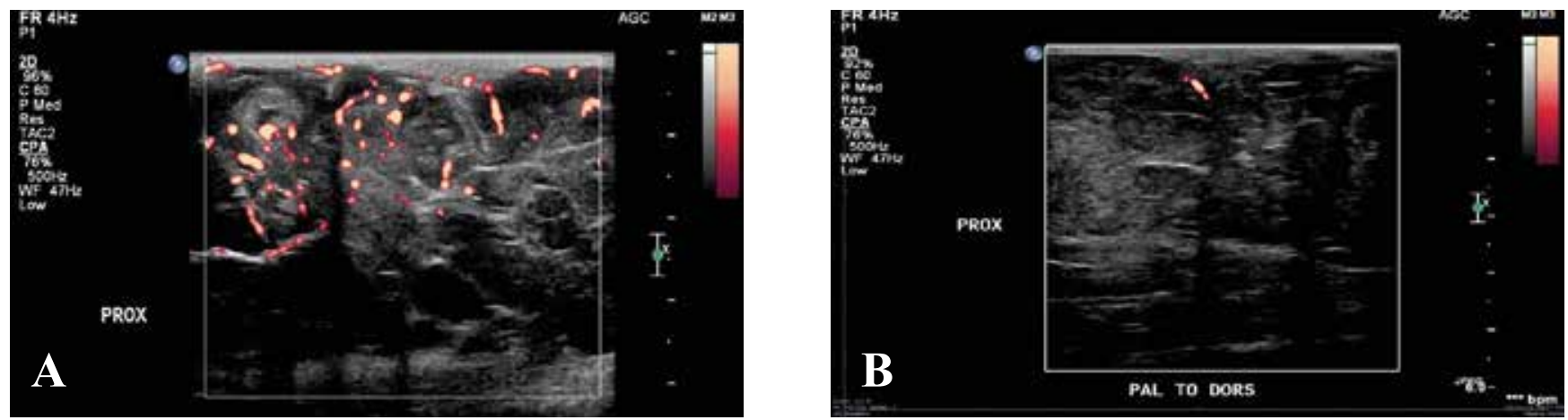

Figure 2 A. Power-Doppler ultrasound images of the tumor before treatment. Blood flow through the tumor is visualized as yellow-red dots. Vascularization is prominent in both the central part of the tumor, as well as at the periphery. B. Power-Doppler ultrasound images of the tumor three days after CA4P treatment. There is minimal blood flow remaining.
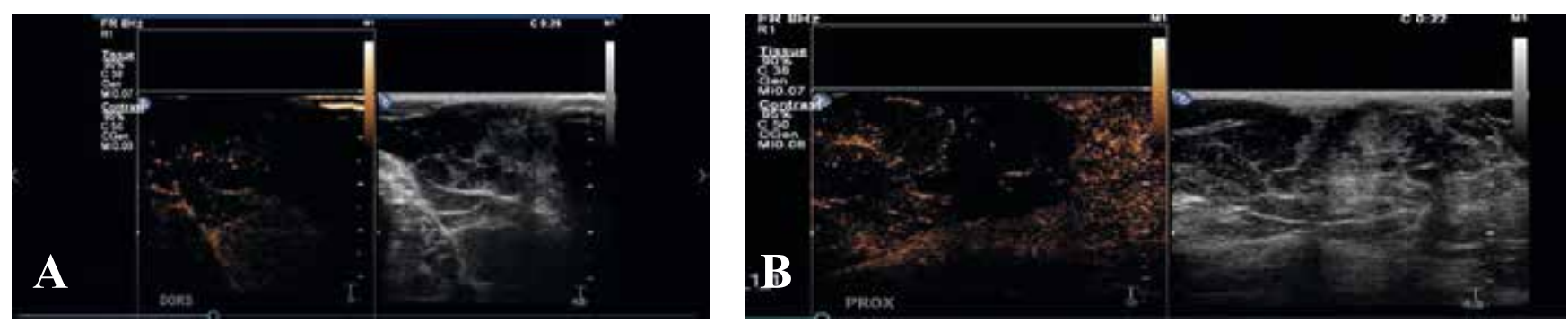

Figure 3 A. B-mode (right) and contrast-enhanced (left) image of the tumor before treatment. The microbubbles, shown in orange, are taken up by the vasculature present in the mass, with a higher uptake in the septa. There is also a diffuse uptake of contrast in a large part of the tumor. B. B-mode (right) and contrast-enhanced ultrasound (left) image of the tumor one day after treatment. The uptake of microbubble contrast is less in het central part of the tumor compared to the periphery; however, the mass can still be identified.

tation with curative intent was advised but declined. The owner reported that the dog had arthrosis in both stifle joints. Furthermore, she firmly believed that a three-legged dog would be an unhappy dog, anyhow. Since PNSTs are not sensitive to chemotherapy, the owner was informed about an ongoing experimental clinical trial on the use of the vascular disrupting agent CA4P in dogs with solid neoplasia.

To obtain more information about the vascularization of the tumor, B-mode, power-Doppler ultrasound (PDUS), contrast-enhanced ultrasound (CEUS) and biopsies were performed. A routine B-mode ultrasonography of the mass was performed and a linear transducer with a frequency of $4 \mathrm{~Hz}$ was used. On Bmode images, the tumor could be defined as a solid mass. The mass was scanned from a dorsal to palmar region and vasculature was prominent and clearly outspoken in de central part as well as at the periphery of the tumor (Figure 2A). For the CEUS images, a linear transducer of $12-5 \mathrm{MHz}$ was used, combined with a frame rate of $8 \mathrm{~Hz}$. There was a large uptake of microbubbles throughout the septa of the tumor and the uptake went from the periphery to the central part of the tumor (Figure 3A). A biopsy of the mass was taken after all imaging was performed and before the treatment with CA4P was started. The protocol used for the sedation was an intravenous injection of both butorphanol (Dolorex ${ }^{\circledR}, 0.2 \mathrm{mg} \mathrm{kg}{ }^{-1}$, MSD, Brussels, Belgium) and dexmedetomidine (Dexdomitor ${ }^{\circledR}$,
$0.005 \mathrm{mg} \mathrm{kg}^{-1}$, Orion Corporation, Espoo, Finland). After sedation and clipping, two six-mm-punch biopsies were taken and sent for histopathologic examination. On the histopathological sections before treatment, hematoxylin and eosin (HE) staining confirmed the diagnosis of malignant PNST (Figure 4A). Additional staining with anti-von Willebrand factor (vWF) was performed to identify vessels in the tissue sections (Figure 5A). Two anti-vWF stainings were made; on each, five fields of view were screened. The anti-vWF-stained slides demonstrated a multitude of viable endothelial cells.

The dog was treated intravenously with a single dose of $75 \mathrm{mg}$ CA4P per $\mathrm{m}^{2}$ dissolved in $10 \mathrm{~mL}$ phosphate buffered saline (PBS), infused over a period of thirty minutes. A PDUS was performed during the infusion and 24 and 72 hours after CA4P-administration. The PDUS images after treatment showed a significant decrease in vascularization compared to the pretreatment images (Figure 2B). Power-Doppler images show that the vascularity index (VI) was at its highest before injection with CA4P. After injection, the VI started to decrease and was low at 24 hours and at its lowest at 72 hours. The vascularization in the central part of the tumor was completely absent; however, in the periphery, a small amount of vascularization remained. One day after treatment, CEUS was repeated. On CEUS images, the uptake of microbubble contrast in the central part of the PNST after treatment 

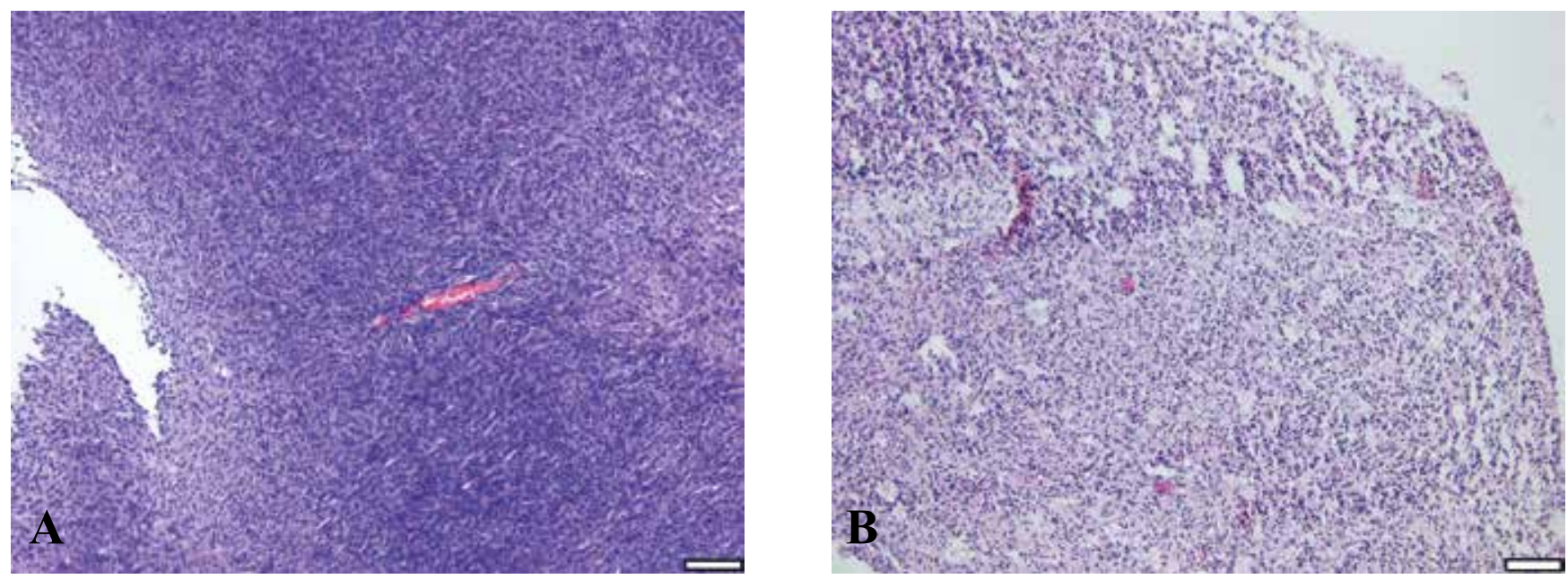

Figure 4 A. Histopathological sections of the tumor before treatment. The tumoral cells are lying in sheets with no differentiation between tumoral cells and fibrovascular stroma. The cells are spindloid with a basophilic nucleus (hematoxylin and eosin; scale bar $=100 \mu \mathrm{m})$. B. Histopathological sections of the tumor three days after treatment. Necrosis can be seen as a big region of eosinophilic amorphous material consisted of cellular and nuclear debris (hematoxylin and eosin; scale bar $=100 \mu \mathrm{m})$.
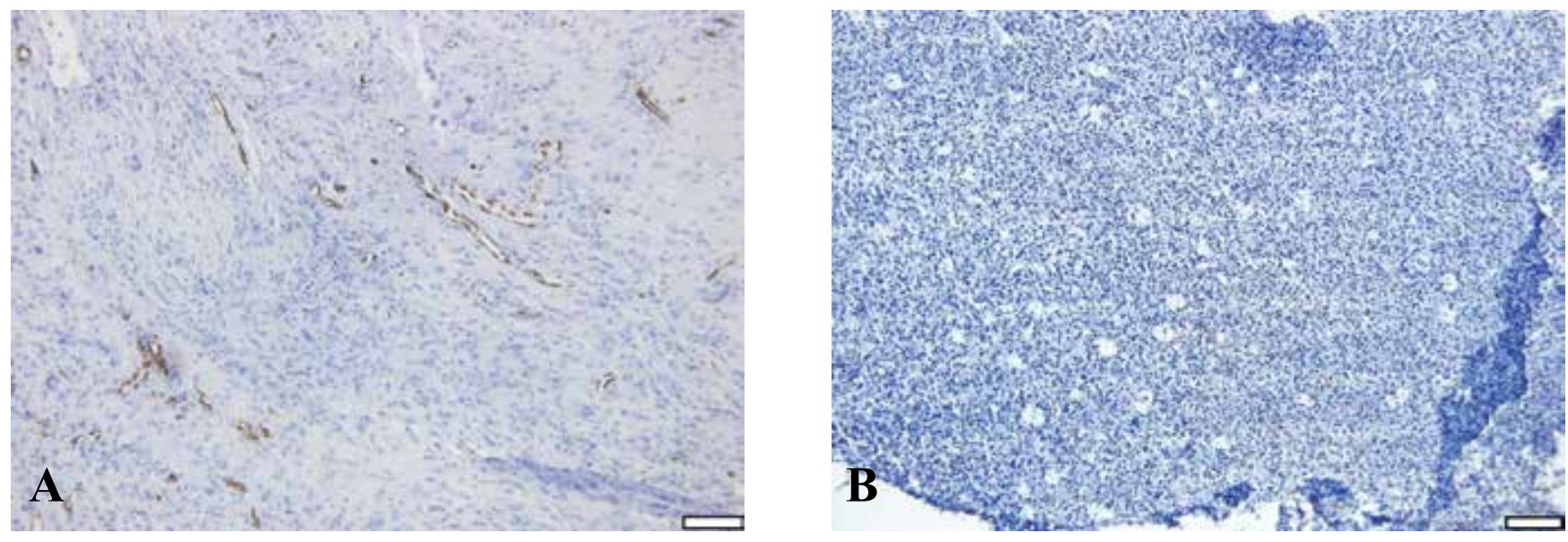

Figure 5 A. Immunohistochemical staining for endothelial cells before treatment. The endothelial cell nuclei are dark brown and the tumoral cells stain blue (anti-von Willebrand factor; Scale bar $=100 \mu \mathrm{m}$ ). B. Immunohistochemical staining for endothelial cells after treatment. There are no endothelial cell nuclei visible after treatment (anti-von Willebrand factor; Scale bar $=100 \mu \mathrm{m})$.

was distinctly less than before treatment (Figure 3B). Biopsies were repeated three days after treatment. On the HE-stained slides, the tumor cells displayed signs of karyorhexis (Figure 4B). In the posttreatment biopsies stained with anti-vWF, the endothelial cells were decreased in number from a mean of $0.21 \%$ before to a mean of $0.06 \%$ after treatment, indicating a reduction in viable endothelial cell density (Figure 5B).

After treatment, the dog remained hospitalized for one week and physical examination was carried out daily. Special attention was given to potential general, cardiovascular and neurological side effects of CA4P treatment. The dog was clinically stable during hospitalization but did experience side effects of CA4P, such as nausea, ataxia on the hind limbs and pain in the tumoral region. Maropitant citrate (Cerenia ${ }^{\circledR}$, Zoetis, Belgium) was administered intravenously and nausea passed in two hours after treatment. For the tumoral pain, Methadon hydrochloride (Comfortan ${ }^{\circledR}$, $1 \mathrm{mg} \mathrm{kg}^{-1}$, Dechra, UK) was administered intravenously every four to six hours. The pain disappeared within 96 hours after CA4P administration. The ataxia was self-limiting and disappeared one week and a half after CA4P administration.

Three weeks after treatment, the tumoral mass was macroscopically decreased in size, and the overlying skin had a less irritated and less ulcerative aspect. Small circular wounds were indicative of the regions where biopsies had been taken (Figure 1B).

The dog returned for further follow-up, weekly for one month, and then monthly for five months. Five months after the CA4P treatment, the remaining mass got infected. Because of the poor response to local and systemic treatment, the owner decided to have the dog euthanized. 


\section{DISCUSSION}

Different options are available when treating a PNST. Local tumor control is the most important consideration in the management of soft tissue sarcomas because of their locally aggressive behavior (Liptak and Forrest, 2013). As such, surgical resection is the main treatment for soft tissue sarcomas. Surgical removal of the mass without adequate margins result in incomplete resection and a high risk of local tumoral recurrence (McKnight et al., 2000; Liptak and Forrest, 2013). In a retrospective study in 51 dogs with a PNST, the overall prognosis after surgical management alone has been shown to be guarded to poor (Brehm et al., 1995). Recurrence and/or development of metastases are associated with decreased survival rate (McKnight et al., 2000). Yet, in this case with a PNST at the level of the carpus in the absence of metastasis, forelimb amputation most likely would have been curative. However, the owner declined such aggressive surgery.

Radiation therapy is often used when treating soft tissue sarcomas. It can be used along with surgery with a curative intent, either preoperatively or postoperatively, or as a sole treatment for pain palliation (Liptak and Forrest, 2013). Similar to other soft-tissue sarcomas, an excellent long-term survival rate may be achieved in some dogs with resection of a PNST followed by radiation (McKnight et al., 2000). Multimodal therapy with marginal surgical excision and postoperative radiation therapy may be limb sparing and reduce patient morbidity (Liptak and Forrest, 2013). The patient described in this case report was not eligible for radiation therapy. Even marginal surgical resection of the tumor would have resulted in a large skin defect, comprising more than half of the leg's circumference. Complications, such as impaired venous and/or lymphatic drainage and the slow healing after free skin grafting, would create a delay in the start of radiation therapy in an attempt to limit the risk of early and late side effects. Palliative radiation therapy was not considered in this case because it has an analgesic rather than a curative intent (Kubicek, 2018); moreover, the tumor was not considered painful to the dog.

The value of chemotherapy in dogs with soft tissue sarcomas, including PNST, is not known (Liptak and Forrest, 2013). In the past, it was claimed that the most promising chemotherapy protocol was doxorubicin (Ogilvie et al., 1989). In the treatment of hemangiosarcoma in dogs, no benefit of combining doxorubicin with another chemotherapeutic agent could be demonstrated (Ogilvie et al., 1996). More recent studies on the efficacy of chemotherapy protocols are not available.

Although not yet FDA-approved as anticancer treatment in domestic animals, CA4P was considered an alternative treatment option in the dog described in this case report. Single IV CA4P treatment resulted in massive necrosis of the malignant PNST. In human patients, CA4P is already FDA-approved for the treatment of several types of cancer and there are preliminary data suggesting that adding CA4P to existing chemotherapy protocols improves overall survival (Garon et al., 2010; Ng et al., 2012; Sosa et al., 2014). Also, the combination of CA4P with radiotherapy is well tolerated in most patients (Ng et al., 2012). Treatment with CA4P can contribute to a longer survival time (Garon et al., 2010). Vascular disruptive agents such as CA4P target and destroy the established tumor vessels. They should not be confused with antiangiogenic agents (AAA); the last interfere with the de novo synthesis of blood vessels, thus preventing the formation of tumor vasculature (Siemann et al., 2005). The exact mechanism behind CA4P has not yet been completely unraveled, but the main action is the disruption of the cytoskeleton of the immature endothelial cells (Siemann et al., 2005). Binding of CA4P leads to tubulin depolymerization, inhibiting further cell proliferation. Consequently, the immature tumoral vessels collapse, leading to tumor hypoxia and necrosis. Because VDAs such as CA4P only target the immature vessels, there is little to no effect on other types of vasculature (Siemann et al., 2005).

In this case, the vascular shutdown effect of a single dose of IV CA4P was evaluated by monitoring the effect on the vascularization of the tumor by three different means. Histopathology, complemented with immunohistochemistry, is still considered the gold standard to assess the treatment effect of antivascular therapy (Gee et al., 2001). The posttreatment surgical biopsies showed clear evidence of vessel destruction and necrosis. Routine histology slides stained with HE revealed zones with necrotic cells, whereas immunohistochemistry staining with anti-vWF identified less endothelial cells. Obviously, US monitoring of the antivascular effect is a more attractive technique than serial biopsies in clinical patients because it is non-invasive. On B-mode images after treatment, the central part of the tumor was more hypoechogenic than the periphery but more specific information could not be gained. Yet, US techniques, such as PDUS and CEUS, reveal information on tissue perfusion through small vessels and the capillary bed, respectively (Wilson et al., 2009). Before treatment, the blood flow in the PNST was prominent throughout the entire tumor and was obvious on both PDUS and CEUS images. On the posttreatment PDUS and CEUS images, there was a marked decrease in vascularization compared to before treatment. It should be noted that PDUS is extremely sensitive to motion, causing flash artifacts that should not be mistaken for blood flow (Rubin et al., 1994). CEUS is an imaging modality that is not yet available to many clinicians, but is considered a promising, sensitive tool to assess in vivo vascularization (Zhang et al., 2017). 


\section{CONCLUSION}

Up to now, conventional treatment of PNSTs has consisted of surgery or palliative radiotherapy. Research proves that VDAs significantly destroy the vasculature of tumoral tissue and lead to necrosis of the tumoral mass. The use of VDAs, such as CA4P, should therefore be further explored in novel combination therapies as alternative treatment options for solid tumors whenever radiation therapy, surgical resection, and/or conventional chemotherapy are not an option.

\section{ACKNOWLEDGEMENTS}

The dog described in this case report was enrolled in a clinical trial that has been funded in part by the Agency for Innovation \& Entrepreneurship under contract number 141020 and by the Belgian Animal Cancer Foundation (BKFD).

\section{REFERENCES}

Abma, E., Daminet, S., Smets, P., Ni, Y., de Rooster, H. (2015). Combretastatin A4-phosphate and its potential in veterinary oncology: a review. Veterinary and Comparative Oncology 15, 184-193.

Abma, E., Smets, P., Cornelis, I., De Clercq, K., Ni, Y., Vlerick, L., de Rooster, H. (2017). A dose-escalation study of combretastatin A4-phosphate in healthy dogs. Veterinary and Comparative Oncology 16, 16-22.

Abma, E., De Spiegelaere, W., Vanderperren, K., Stock, E., Van Brantegem, L., Cornelis, I., Daminet, S., Ni, Y., Vynck, M., Verstraete, G., Smets, P., de Rooster, H. (2018). A single dose of intravenous combretastatin A4phosphate is reasonably well tolerated and significantly reduces tumour vascularization in canine spontaneous cancers. Veterinary and Comparative Oncology, https:// doi.org/10.1111/vco.12402.

Brehm, D.M., Vite, C.H., Steinberg, H.S., Haviland, J., van Winkle, T. (1995). A retrospective evaluation of 51 cases of peripheral nerve sheath tumors in the dog. Journal of the American Animal Hospital Association 31, 349-359.

Cornelis, I., Van Ham, L. (2009). Perifere zenuwschedetumoren bij kleine huisdieren: een literatuuroverzicht en classificatie. Vlaams Diergeneeskundig Tijdschrift 78, 401-407.

da Costa, R.C., Parent, J.M., Dobson, H., Ruotsalo, K., Holmberg, D., Duque, M.C., Poma, R. (2008). Ultrasound-guided fine needle aspiration in the diagnosis of peripheral nerve sheath tumors in 4 dogs. The Canadian Veterinary Journal 49, 77-81.

Dowlati, A., Robertson, K., Cooney, M., Petros, W.P., Stratford, M., Jesberger, J., Rafie, N., Overmoyer, B., Makkar, V., Stambler, B., Taylor, A., Waas, J., Lewin, J.S., McCrae, K.R., Remick, S.C. (2002). A phase I pharmacokinetic and translational study of the novel vascular targeting agent combretastatin A-4 phosphate on a single-dose intravenous schedule in patients with advanced cancer. Cancer Research 62, 3408-3416.

Farese, J.P., Bacon, N.J., Liptak, J.M., Kow, K. (2012). Introduction to oncological surgery for the general surgeon.
In: Veterinary Surgery Small Animal. First Edition, Saunders Elsevier, St. Louis, MO, USA, pp. 304-324.

Galbraith, S.M., Chaplin, D.J., Lee, F., Stratford, M.R., Locke, R.J., Vojnovic, B., Tozer, G.M. (2001). Effects of combretastatin A4 phosphate on endothelial cell morphology in vitro and relationship to tumour vascular targeting activity in vivo. Anticancer Research 21, 93-102.

Garon, E.B., Kabbinavar, F.F., Neidhart, J.A., Gabrail, N.Y., Oliveira, M.R., Lu, S.P., Balkissoon, J. (2010). Randomized phase II trial of a tumor vascular disrupting agent fosbretabulin tromethamine (CA4P) with carboplatin (C), paclitaxel (P), and bevacizumab (B) in stage IIIb/IV nonsquamous non-small cell lung cancer (NSCLC): the FALCON trial. Journal of Clinical Oncology 28, 7587.

Gee, M.S., Saunders, M.I., Lee, J., Sanzo, J.F., Jenkings, T., Evans, S.M., Trinchieri, G., Sehgal, C.M., Feldman, M.D., Lee, W.M.F. (2001). Doppler ultrasound imaging detects changes in tumor perfusion during antivascular therapy associated with vascular anatomic alterations. Cancer Research 61, 2974-2982.

Griggs, J., Metcalfe, J.C., Hesketh, R., (2001). Targeting tumour vasculature: the development of combretastatin A4. The Lancet Oncology 2, 82-87.

Kanthou, C., Greco, O., Stratford, A., Cook, I., Knight, R., Benzakour, O., Tozer, G. (2004). The tubulin-binding agent Combretastatin A-4-phosphate arrests endothelial cells in mitosis and induces mitotic cell death. American Journal of Pathology 165, 1401-11.

Kubicek, L., DVM, DACVR. https://www.mspca.org/angell_services/the-role-of-palliative-radiation-therapy-inveterinary-medicine/, assessed on 04/10/18.

Li, J., Chen, F., Feng, Y., Cona, M.M., Yu, J., Verbruggen, A., Zhang, J., Oyen, R., Ni, Y. (2013). Diverse responses to vascular disrupting agent combretastatin A4 phosphate: a comparative study in rats with hepatic and subcutaneous tumor allografts using MRI biomarkers, microangiography, and histopathology. Translational Oncology 6, 42-50.

Liptak, J.M., Forrest, L.J. (2013). Soft tissue sarcomas. In: Withrow, S.J., Vail, D.M., Page, R.L. (editors). Small Animal Clinical Oncology. Fifth edition, Saunders, Philadelphia, USA, p. 356-380.

McKnight, J.A., Mauldin, N., McEntee, M.C., Meleo, K.A., Patnaik, A.K. (2000). Radiation treatment for incompletely resected soft-tissue sarcomas in dogs. Journal of the American Veterinary Medical Association 217, 205-210.

Ng, Q.S., Mandeville, H., Goh, V., Alonzi, R., Milner, J., Carnell, D., Meer, K., Padhani, A.R., Saunders, M.I., Hoskin, P.J. (2012). Phase Ib of radiotherapy in combination with combretastatin-A4-phosphate in patients with non-small-cell lung cancer, prostate adenocarcinoma, and squamous cell carcinoma of the head and neck. Annals of Oncology 23, 231-237.

Ogilvie, G.K., Reynolds, H.A., Richardson, R.C., Withrow, S.J., Norris, A.M., Henderson, R.A., Klausner, J.S., Fowler, J.D., McCaw, D. (1989). Phase II evaluation of doxorubicin for treatment of various canine neoplasms. Journal of the American Veterinary Medical Association 195, 1580-1583.

Ogilvie, G.K., Powers, B.E., Mallinckrodt, C.H., Withrow, S.J. (1996). Surgery and doxorubicin in dogs with hemangiosarcoma. Journal of Veterinary Internal Medicine 10, 379-384.

Poston, G.J. (2007). Is there a surgical oncology? In: Poston, 
G.J., Beauchamp, R.D., Ruers, T.J.M. (editors). Textbook of Surgical Oncology, Informa Healthcare. First edition, Informa Healthcare, London, UK, p. 1-4.

Remick, S.C. (2009). A phase II trial of Fosbretabulin in advanced anaplastic thyroid carcinoma and correlation of baseline serum-soluble intracellular adhesion molecule-1 with outcome. Thyroid 19, 233-240.

Rubin, J.M., Bude, R.O., Carson, P.L., Bree, R.L., Adler, R.S. (1994). Power doppler US: a potentially useful alternative to mean frequency-based color Doppler US. Radiological Society of North America 190, https://doi. org/10.1148/radiology.190.3.8115639

Rustin, G.J., Galbraith, S.M., Anderson, H., Stratford, M., Folkes, L.K., Sena, L., Gumbrell, L., Price, P.M. (2003). Phase I clinical trial of weekly combretastatin A4 phosphate: clinical and pharmacokinetic results. Journal of Clinical Oncology 21, 2815-2822.

Saunders, J.H., Poncelet, L., Clercx, C., Snaps, F.R., Flandroy, P., Capasso, P., Dondelinger, R.F. (1998). Probable trigeminal nerve schwannoma in a dog. Veterinary Radiology and Ultrasound 39, 539-542.

Siemann, D.W., Bibby, M.C., Dark, G.G., Dicker, A.P., Eskens, F.A.L.M., Horsman, M.R., Marmé, D., LoRusso, P. (2005). Differentiation and definition of vascular-targeted therapies. Clinical Cancer Research 11, 416-420.

Sosa, J.A., Elisei, R., Jarzab, B., Balkissoon, J., Lu, S.P., Bal, C., Marur, S., Gramza, A., Yosef, R.B., Gitlitz, B., Haugen, B.R., Ondrey, F., Lu, C., Karandikar, S.M., Khuri, F., Licitra, L., Remick, S.C. (2014). Randomized safety and efficacy study of fosbretabulin with paclitaxel/ carboplatin against anaplastic thyroid carcinoma. Thyroid 24, 232-240.

Stevenson, J.P., Rosen, M., Sun, W., Gallagher, M., Haller, D.G., Vaughn, D., Giantonio, B., Zimmer, R., Petras, W.P., Stratford, M., Chaplin, D., Young, S.L., Schnall, M., O’Dwyer, P.J. (2003). Phase I trial of the antivascular agent combretastatin A4 phosphate on a 5-day schedule to patients with cancer: magnetic resonance imaging evidence for altered tumor blood flow. Journal of Clinical Oncology 21, 4428-4438.

Targett, M.P., Dyce, J., Houlton, J.E.F. (1993). Tumours involving the nerve sheaths of the forelimbs in dogs. Journal of Small Animal Practice 34, 221-225.

Vanderperren, K., Stock, E., Haers, H., Van der Vekens, E., De Ridder, M., Sanders, N., de Rooster, H., Saunders, J.H. (2014). Ultrasound and contrast-enhanced ultrasound imaging of various mammary gland lesions in companion animals. Southern European Veterinary Conference, Barcelona.

Wilson, S.R., Greenbaum, L.D., Goldberg, B.B. (2009). Contrast-enhanced ultrasound: what is the evidence and what are the obstacles? American Journal of Roentgenology 193, 55-60.

Young, S.L., Chaplin, D.J. (2004). Combretastatin A4 phosphate: background and current clinical status. Expert Opinion on Investigational Drugs 13, 1171-1182.

Zanetta, L., Marcus, S.G., Vasile, J., Dobryansky, M., Cohen, H., Eng, K., Shamamian, P., Mignatti, P. (2000). Expression of Von Willebrand factor, an endothelial cell marker, is up-regulated by angiogenesis factors: a potential method for objective assessment of tumor angiogenesis. International Journal of Cancer 8, 281-288.

Zhang, P., Chen, Y., Liu, J., Yang, Y., Lv, Q., Wang, J., Zhang, L., Xie, M. (2017). Quantitative evaluation of combretastatin A4 phosphate early efficacy in a tumor model with dynamic contrast-enhanced ultrasound. Ultrasound in Medicine \& Biology 44, 840-852.

Zweifel, M., Rustin, G. (2010). The clinical development of tubulin binding vascular disrupting agents. In: Meyer. T. (editor). Vascular Disrupting Agents for the Treatment of Cancer. Springer, New York, p. 188. 